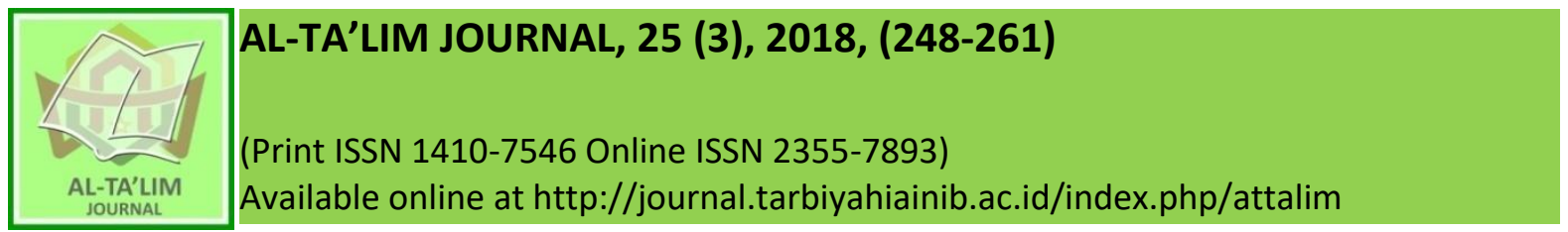

\title{
The Development of Learning Model With An-Nafs Learning Theory
}

Received: $07^{\text {th }}$ July 2018; Revised: $04^{\text {th }}$ September 2018; Accepted: $26^{\text {th }}$ November 2018

Permalink/DOI: http://dx.doi.org/10.15548/jt.v25i3.344

\section{Ahmad Rivauzi}

Universitas Negeri Padang, Indonesia

E-mail: ahmadrivauzi@fis.unp.ac.id

\begin{abstract}
This article aims to explore the theory, An-Nafs learning model and the response of religious teachers at elementary schools in Palupuh, Agam. This study involved all the religious teachers from 19 schools in Palupuh. Based on the questionnaire distributed and then processed by using Likert scale, obtained excellent response from them, both on the aspects of theoretical understanding, urgency, and the benefits of its application to the learning of Islam. The finding showed that all the learning theories today can not be separated from the philosophical view of the nature of man and God. This view will determine how a person treats humans, educates and learns them and also the purpose of the education and learning. The essence of learning in the theory and model of learning An Nafs is the occurrence of changes in the An-Nafs itself as the potential human-psychological (jasad-ruhani).
\end{abstract}

Keywords: Learning Models; An-Nafs Theory; Response

How to cite: Rivauzi, A. (2018). The development of learning models with an-nafs learning theory. Al-Ta Lim Journal, 25(3). doi:http://dx.doi.org/10.15548/jt.v25i3.344

\section{INTRODUCTION}

According to Kolb, Boyatzis, \& Mainemelis (2001); Merriam (2001); Sanjaya (2006); Vidyasagar (2002), every learning theory that develops today based on a view of human nature. This view is related to the views of John Locke and Leibnitz. According to John Locke, the human is a passive organism with his tabular theory that puts humans like a white paper, to be written whatever depends on the authors. From this theory was born the behavioristicelementaryistic learning theory (Ægisdóttir \& Pórhallsdóttir, 2004; Hale \& Reiss, 2003). While Leibnitz considers that humans are active organisms. Human are the source of all activities, free to do and choose various situations. From this Leibnitz view was born the flow of cognitive-holistic learning theory.
Basically, behavioristic and cognitive theory have logical truth aspects, but on the other hand, this theory also has a weakness caused by the inability theories in explaining human nature, especially when related with ontological aspects such as the nature of existence and human relationships with His God (Bandura, 2005; Miller, 2003; Ullrich, 2008).

This research is library research. Basically literature research belongs to the qualitative research because of the interpretation and the search for meaning from written texts (Suyanto, 2005). Library research focuses on the study and tracing of ideas on literary sources such as texts and so on (Sutrisno, 2000).

This paper is intended to discuss alternative learning theories that developed 
from Islamic perennial sources, especially the Qur'an, Hadits, and various Islamic religious leteratures.

\section{METHOD}

This research was field research that aims to see how are the response of the religious teachers at elementary schools in Palupuh, Agam throught the theory and model of learning An-Nafs. It has done at 14th of october 2017 In Palupuh, Agam west Sumatera. There are 19 elementary schools with total number of religious teachers are 20 people. This study involved all of them. Data collection techniques used in this study was indirect communication with used the instrument such as questionnaire. The result data is processed by using Likert scale. This Likert scale can be used as a measurement method to measure attitudes, opinions, and perceptions of a person or group of people against a social phenomenon (Margono, 2005; Sugiyono, 2008).

\section{Learning Theory of An-Nafs}

According to Simandan (2013), learning theory is a conceptual framework that describes haow knowledge is absorbed, processed, and maintained. Cognitive, emotional, and environmental influences, as well as previous expaeriences, all contribute to how the understanding, and the worldview are acquired become the knowledge and skills that are maintained and developed (de Corte, Verschaffel, Entwistle, \& Van Merriënboer, 2003; Illeris, 2004b, 2004a; Yang, Watkins, \& Marsick, 2004).

Thus, learning theory is a conceptual framework that describes how knowledge, attitudes, and skills are absorbed, processed, maintained and even developed as a result of the process of cognitive, emotional, spiritual, and environmental influences, and previous experiences, all of them play a role in how knowledge, understanding, skills and worldviews, acquired, altered maintained and developed.
While the learning model is the whole set of presentation of teaching materials that covering all aspects before, during, and after the learning of the teacher and all related facilities used directly or indirectly in the teaching and learning process (Nurdyansyah \& Fahyuni, 2016).

Based on the understanding above, so the theory of learning will give birth a model of learning that consists of a series of approaches, strategies, methods, techniques and even learning tactics into a unity. In other words, the learning model is the framework of the application of an approach, method, and learning technique.

The approach can be viewed from two perspectives. First, in the context of a view that education as an eventual process that embodies, reinforces, strengthens, and underlies methods and learning processes with a particular theoretical. So in this perspective the approach can be interpreted as a point of or a perspective of the event in the educational process. Wina Sanjaya defines the approach in this perspective so that there are two approaches: (1) the student centered approach and (2) the teacher centered approach (Brown, 2003; Karabenick, 2003; Pang, 2001; Schaefer \& Zygmont, 2003). Second, the approach is defined in the perspective of a process that approaching an object or interpreted by come near (come over), go to (path to), and way path (road). In this sense, the approach is defined as a way of approaching or coming to something. Yahya (2006), defines the approach by processing the subject of the object to achieve the goal.

The strategy was originally used in a military world defined by the use of all the power of military to win a war. In the world of education, strategy is defined as a plan, method, or series of activities designed to achieve a particular educational goal Thus, strategy means planning that contains a series of activities that designed to achieve a more effective and effective educational goal (Darby, 2007; Schmeck, 2013). Gustafson \& Branch (2002) also explained that strategy is 
an activity of education and learning that must be done by teachers and students so that the learning goal can be achieved effectively and efficiently. O'Neil (2014); Weinstein, Husman, \& Dierking (2000) classified learning strategies into discovery-learning expression strategies, group learning strategies and individual learning strategies.

The method is the way used to apply the plan that has been prepared. Thus, the method is the way of realizing the learning strategy, on the other hand, Technique is the way that someone does in order to imply a method. For example, what should be done to make the lecture method is effective. While tactics are a person's style in implementing a particular method. So, tactics are individual. Tactics are a person's style in carrying out a particular technique or method. Tactics are more individual. Although two people used a same method, they will definitely do it differently in terms of language style, posture, etc.

\section{The Foundation of Philosophy and Understanding of Learning An Nafs}

Basically, learning is the process of developing the human fithrah and flash back to the agreement with God in the natural ruh. In this context, learning can be said as the process of developing Qalbu or education heart (Qalbu) (Hamzah, Isa, \& Janor, 2010; Kobeisy, 2006; Razak, 2011).

Al-Ghazali explains that the nafs is the same as the spirit (ruh-ruhani). Nafs has the nature of the land (al-Thiniyyat) and fire (alnariyyah), while the spirit is like light (alnuriyyah) and ruhani (al-ruhaniyyah). Nafs is humanity (al-nasutiyyah), while the spirit is deity (al-lahutiyyah) (Baharuddin \& Ismail, 2015; Sa'ari, 2002). So Ibn Qayyim concluded that the spirit and nafs are the same substance, but different in character. This conclusion is similar to the view of Ikhwan al-Shafa on the similarity of the essence or the substance of the spirit with the Nafs (A. Mujib, 2012; Mujib, 2006).
Qalbu, as described by scholars, can be viewed as a form of organic matter found on human bodies, and can be viewed as a system of emotional cognition (Mujib, 2017).

The concept of learning An-Nafs based on philosophical foundation: human not merely as a being composed of the physical aspect only, but the essential essence of the human as a spiritual being who assumes the duties of God's servant. Nafs is the name for the spirit when the spirit has not been blown into the human body (Munsoor, 2015; Pathan, 2016; Rothman \& Coyle, 2018; Ubale \& Abdullah, 2015). The blowing of the spirit to the body occurs when the body is ready to receive it. According to Hadìts, that readiness is when a human is four months in the womb mother. When the soul is blown into the body,at the moment the spirit changes its nature and name into An-Nafs. Although different traits, but the spirit and nafs remain the same substance.

An-Nafs has the power and potentialities as an energy of spiritual in education and learning. The learning model of An-Nafs departs from the concept of education based on the values and dimensions of Islamic spirituality. The spiritual-based education is based on the belief that educational activity is a worship of Allah swt. Human was created as a holy servant of God and given the mandate to preserve the holiness. In general, spiritual-based education focuses on spirituality as the primary potential for mobilizing every act of education and instruction, in this sense, it is understood as a normative source of inspiration in educational and teaching activities, and also spirituality as an educational goal. The spiritual purpose intended here is the realization of the consciousness of servanthood to Allah SWT (Pransiska, 2016; Sad, 2004; Solichin, 2007).

The essence of learning in the theory of learning An Nafs is the changing of nafs itself as a psycho-psychic potential through the absorption of knowledge, skills and values processed, maintained and developed to produce the personal figure of nafs muthmainnah and able to have value and behave the rahmatan li al-'alamin. 
An-Nafs learning model as a model of learning, consists of a series of approaches, strategies, methods, techniques, and learning tactics as a whole based on education and learning that makes the spirit as a basis, sabjek and object of education and learning with the aim is to realize the human kamil as servants and khalifah of Allah SWT.

\section{Approach in Learning An Nafs}

Referring to the verses in the $\mathrm{Al}$ Qur'an, there are at least three approaches in the An-Nafs learning theory:

a. Approach 'Aqliyyah (philosophical). The words' aqal in al-Quran in various compositions repeated as many as 49 times on several letters and verses. Among them are in QS, Al-Hajj, 22: 46: "... then do not they walk on the earth, then they have hearts with which they can understand or have ears to which they can hear? For indeed it is not the blind eye, but the blind is the heart in the breast ". 'Aqal is an-nafs activity but uses the physical brain. If the sensing nafs uses Qalbu, so the view is spiritual (taste and intuition), but if the senses sense through sense, then the sensing is physical that is through the brain whose the characteristics are rational logic.

b. Approach Qalbiyyah (Dzauqiyah). AlGazhali (tt: 4-5) in Ihya; sees the Qalbu from two aspects, the physical aspect (the physical heart) or the meat is like a heart of banana which is located the chest of the left, and the spiritual heart,that is something unseen (lathif ), Rabbani, and the Soul. Qalbu in this spiritual sense is the essence of human. Qalbu physical is the heart (heart) which became the center of the human body that serves as the center of circulation and regulation of blood. If this function stops, then the dead (limit) of human life is exhausted and there is death. Qalbu in the spiritual sense is only possessed by human, which is the center of his personality. However, physical Qalbu and Qalbu-ruhani have interrelated relationships. Qalbu has a tendency to accept the truth of Allah because it is also called the nature ilahiyah as the supra consciousness aspect from Allah. Qalbu has an emotional power; love, happiness, hate, sadness, and disbelief, cognition power that is subtle and rabbani which can achieve the essence of something (ma'rifah) through the power of taste (aldzawqiyyah) and intuition (al-hadsiyyah) by purifying themselves (tazkiyat AnNafs). Qusyairi said that knowledge of qalbiyah is much wider and deeper than aqliyyah's knowledge. Aqal can not know the nature of God, while Qalbu can know the nature that exists.

c. Approach 'amaliyah. In the Al-Quran, the words of faith (iman) are often related with the good deeds (amal shaleh). (Rosidin, 2011), collected all the Al Qur'an verses that containing the pious charity (amal shaleh) that accompanied the words of faith amounted to 19 repetitions in singular form. While the word 'charity in various forms of composition it amounted to 359 repetitions. This shows that the activity which is the meaning of charity is an important thing in Islam (Chalil, 2009; Majid, 2011; Nasrudin \& Herdiana, 2015).

Among the verses that describe above about good deeds (amal shaleh) for example in $Q S$. Saba ', 34:37; QS. An-Nahl, 16:97; QS. Al-Qashash, 28:67; and QS. Al-An'am, 6: 132. These verses illustrate the importance of charity in a broad sense and affirm that good life, good luck, good level are the rights that will be accepted by the people who do activity and in the activity contains good values. Thus, in education, a teacher with his students must place all learning activities as worth individually and socially (Rivauzi, 2014).

\section{An-Nafs Learning Strategy}

Allah says in QS. Al-Baqarah, 2: 151: "... We have sent unto you the Messenger (rasul) among you who recited Our Signs to you and sanctified you and taught you $\mathrm{Al}$ Kitab and Al-Hikmah (As Sunnah), and taught you what you do not yet know". 
In the verses above, there are 3 (three) learning strategies, namely: Tilawah strategy. (Shihab, 2006, 2007), explains the meaning of recitations in the scope of reading the verses qauliyyah based on the words of Allah in $Q S$. Al-Baqarah, 2: 252 and QS. Al-Maidah, 5:27. The tilawah strategy is an activity to exposure the teaching material through reading, studying and meditating on the verses of Allah. The goal to be achieved is the consciousness of divinity. This activity is also called learning activities through expository strategy. In this strategy, the teacher reads, presents and shows the verses of Allah (signs of God's existence and majesty) through the verses qauliyah (Al-Quran) that is associated with the universe or all creatures of Allah (verse kauniyah) which serves to explain to human about the existence of Allah (the Creator).

"Verily in the creation of the heavens and the earth, and the changing of night and day there are signs for those who are understanding, those who remember Allah while standing or sitting or in a lying-down order and they think about the creation of the heavens and the earth (saying): "Our Lord! You have not created this in vain, Glory to You, so save us from the torment of hell." (Surah Ali Imran, 190-191) ".

Strategy tazkiyah is an activity that requires the activity of both teachers or learners in doing riyadhah (spiritual exercise) that is spirituality (SQ). In this activity, teachers and learners are required to provide the meaning and the interpretation of learning activities as something worship to God (Allah).

The ta'lim strategy is an activity of studying knowledge and wisdom. The word al-Kitab in the verse of Allah (QS. AlBaqarah, 2: 151) above can mean scripture and everything written in the ilmiyah books. While the word wisdom shows the establishment of personality, ability and understanding and also the ability to say the right and the right action. According to Sanaky (2003, 2008), wisdom means an understanding and a science. Wisdom also means understanding or words and actions that are true ( قو لا وعملا الفقه او الصواب). Words that are not accompanied by actions, are threatened with a curse, like His Word: "There is great heat in the sight of Allah that you say what you do not do". (QS. as-Shaf).In Arabic, the word judge does not mean as a judge as a judge in Indonesian. In Arabic, the person who is judged is called al-Qadhi, while the thinker in the field of law is called the fuqaha '. The scholars also equate the word wisdom with the word philosophy which means wisdom (Abuddin, 2011).

\section{An Nafs Learning Methods}

Rivauzi (2014) wrote several methods that can be used in the theory of learning $A n$ Nafs:

a. Lecture method (tabligh. Teacher is a transmitter. Tablig (تبليخ) is mashdar of (بلغ) which implies taktsir (تكثير) which means a lot. Sometimes this (taktsir) meaning is to the fi'il (its action) and sometimes to its object (maf'ul) (Imam almuhaqqiq al-Mudaqqiq Ahmad Rusydi, $\mathrm{tt}$ : 4). This method is suitable for use in recitations strategy. The Prophet Muhammad says in Hadīts of Abi Kabsyah, in Shahih Bukhari, juz 4: 170, no. 3461, he said: "I heard Abdullah bin Umar: I heard Prophet Muhammad says. "Convey by you from me even one verse". (H.R. Ad Dārimy)

b. Methods of Muhasabah, zikir and prayers. Muhasabah means selfevaluation. Muhasabah will sharpen the inner eye to see the goodness that God has given. Muhasabah (محاسبة) is formed from the word حاسب - يحاسب - محاسبة which means musyarakah ( بين الأثنين بداب which means union between two persons or it means association to one person such as قاتل هم الله it means Allah has killed them (Ahmad Rusydi, tt: 4). But if a similar word is linked to a human, so the meaning is the union between two persons. The method of muhāsabah is used to invite the learners to do reflection. This method is suitable for tazkiyah strategy. Allah says: Those who are righteous when they are 
overwritten from shaitan, they remember Allah, then also they see his mistakes. (QS. Al-A'raf, 07: 201). (al-Muhasibi, 2010) says, "fear God in your religion; look to Him in all your affairs; and be patient for the suffering that befell you. " God is close to the one who prays in secret ". Zikir (remembrance of Allah), is the road to al-Haqq. Zikr is generally divided into two, namely oral zikir and heart zikir (Faruq, 2007). Ibn Taymiyya said that the zikir for the heart is like water for the.

c. Discussion method (muhawarah). Hiwar is also often interpreted with a meaningful dialogue of questioning, chatting. Muhawarah also has the meaning musyarakah baina al-itsnain as well as the meaning of Muhasabah. Among the words of Allah that use the word muhawarah: And he has great wealth, so he said to his friend (who mu'min) when he chatted with him: "My treasure more than your wealth and my followers stronger". (QS. Al-Kahf, 18:34)

d. Method of demonstration (uswah). In this demonstration method or uswah, a teacher as an example and show something to his students and asks his students to follow him. Uswah as a method of learning has been exemplified by the Prophet Muhammad. Malik bin Huwairits r.a., he said: "We came to Prophet Muhammad and we were the same peers We stayed with him for 20 nights The Prophet (peace be upon him) was a merciful man, and when he thought we had wanted to go home and miss the family, he asked about the people we left behind and we told him. He said: 'Come back to your family and stay with them, teach them and tell them.' He mentioned things that I memorized and I did not memorize.'And pray as you see me praying When the (time) of prayer arrives, then let one of you adzan and the most mature become faith. (H.R. Bukhari)

e. An educational hit method. The point of hitting here is not a reflection of anger and hate, but only as a form of physic discipline. This method of educating by hitting is of course only true when the children are at the age of children and puberty. In this case Abu Dawud and Hakim narrated from Amar bin Syu'aib from his father from his grandfather, that the Prophet Muhammad (SAW) said: command your children to perform sholat when they are seven years old, if they are ten years old then beat them (if still do not want to pray), and separate their beds (Abu Daud and Hakim).

f. Method of excommunication (ithrah). This method is the last method taken if good advice and other methods do not work to change the behavior of an adult to be better. The Prophet Muhammad also did the excommunication punishment for the disobedient to Allah.

Al-Bukhari said that Ka'ab told of himself (with two other friends) left behind from the Prophet, because Ka'ab and his two friends did not want to join the Tabuk war. Because of our disobedient (the word Ka'ab), the Prophet Muhammad has forbidden the Muslims to talk with us for 50 days and nights ". This boycott or excommunication makes Ka'ab and his friend feel the world is narrow, and the exclusion ends when the revelation that tells that their repentance has been received by Allah. Prophet Muhammad also isolated or silenced some of his wives for one month as punishment and lesson for them (Nashih'Ulwan, 2012). Of this method of excommunication, it is called God in the Quran for example by the title ithrah: kill Yusuf or throw him into an unknown territory so that your father's attention may be spilled upon you, and then you shall be good men. "(QS. Yusuf, 12: 9)

\section{An-Nafs Education and Learning Technique}

a. Bi al-hikmah technique. Bi al-hikmah technique is a learning technique that emphasizes the principle of a teacher's credibility. 
b. Mau'izhah hasanah technique. Technique Mau'izhah hasanah is teaching or advice in a good way. A teacher must be able to perform ethical communications and inner communication through the touch of a heart language. The meaning of ihsan is expressed in the Hadits of Muslim history from Yahya bin Ya'mar, that Jibril came to the Prophet Muhammad, and teach about three things; Islam, Faith, and Ihsan ..... Jibril asked the Messenger of Allah ; Explain to me about Ihsan! the Prophet Muhammad answered; Ihsan is worshiping God as if you saw Him. If you do not see Him, He sees you ... (Muslim)

c. Mujadalah hasanah technique. Mujadalah is a debate. This mujadalah technique can be used on discussion or muhawarah method. About bi al-hikmah, mau'izhah, and mujādalah techniques are illustrated in the word of God: "Call (human)into Allah ways with wisdom and good lessons and dispute them in a good way. Your Allah is the one who knows more about who is lost from His ways and who is the one who knows the guided. ( $Q S$. an-Nahl: 125)

d. Amtsal technique. The amtsal technique can be applied in a method or lecture (tabligh). In this case, amtsal means to think of something abstract with another more concrete. Among the words of Allah who call the technique are: probably they are like the one who lights the fire, then after the fire illuminates the surroundings God removes the light (which illuminates) them, and leaves them in darkness, unable to see. (QS. AlBaqarah, 2:17)

e. The 'ibrah fi al-qishshah technique. Qishshah is often interpreted by telling stories. Storytelling is one of the techniques in lecture method In $\mathrm{Al}$ Qur'ān, Allah describes this technique between the QS Yusuf, 12: 3, 111 and QS. Al-Hashr, 59: 2. Qisshah in al-Quran is derived from the word "al-qashshu" which means looking for traces. In terminology, qishshah means preaching about the things of the past or events that happened in the past.

f. Targhib wa Tarhib technique. Targhib رغب - يرغب words taken from the Arabic - which means liking and loving. The meaning contained in this word also contains many meanings. Thus, targhib as a teaching technique emphasizes the teacher's efforts in bringing good tidings and creating a fun atmosphere in learning. While the words tarhib comes from the word "rahhaba" which means scaring with the punishment. In applying this learning technique, targhib should be done more often than tarhib.

g. Tajrib (exercise) technique. This technique emphasizes the importance of repetition and practicethe good things. This habit can be showed by teachers and familiarized by learners so that it becames a permanent habit.

\section{Tactics in Learning An-Nafs}

As for educational tactics, the verses of al-Quran talk about gentle, and the things that make learners feel comfortable and safe with teacher. Gentle giving the students a cool and comfortable feeling that is the main prerequisite for them to bringt their learning creativity. Allah says: "It is because of the mercy of Allah that you are gentle in their behalf, if you have been hard again, they will be distanced from all around you (QS. Ali Imran: 159).

Table 1. Comparison between An-Nafs Learning Theory and Behavioristic and Cognitive Learning Theory

\begin{tabular}{|c|c|c|}
\hline The Behavioristic Learning Theory & $\begin{array}{c}\text { The Cognitive Learning } \\
\text { Theory }\end{array}$ & An-Nafs Learning Theory \\
\hline $\begin{array}{l}\text { Concerned with the environmental } \\
\text { influences }\end{array}$ & Concerned with what is inside & $\begin{array}{lll}\text { Humans } & \text { are } & \text { influenced by } \\
\text { internal } & \text { and } & \text { environmental } \\
\text { factors } & & \end{array}$ \\
\hline Concerned sections (change of behavior is & concerned overall & Meaningfulness of the whole \\
\hline
\end{tabular}




\begin{tabular}{|c|c|c|}
\hline The Behavioristic Learning Theory & $\begin{array}{l}\text { The Cognitive Learning } \\
\text { Theory }\end{array}$ & An-Nafs Learning Theory \\
\hline broken down into sections behaviors) & & without ignoring the parts \\
\hline $\begin{array}{l}\text { Giving priority to the role of reaction } \\
\text { (readiness to respond) }\end{array}$ & Prioritizing cognitive function & Readiness Reaction and cognition \\
\hline $\begin{array}{l}\text { Learning outcomes are formed } \\
\text { mechanically }\end{array}$ & A balance within ourselves & $\begin{array}{l}\text { In the end, learning outcomes are } \\
\text { formed due to a balance of inner }\end{array}$ \\
\hline Influenced by past experience & $\begin{array}{l}\text { Depending on the current } \\
\text { conditions }\end{array}$ & $\begin{array}{l}\text { Can be influenced by past and } \\
\text { current conditions }\end{array}$ \\
\hline Habituation & $\begin{array}{l}\text { Concerned with the formation } \\
\text { of the structure cognition }\end{array}$ & $\begin{array}{l}\text { Habituation and cognition } \\
\text { formation }\end{array}$ \\
\hline Solve the problem by trial and error & $\begin{array}{l}\text { Solve problems based on the } \\
\text { insight }\end{array}$ & Experience and insight \\
\hline
\end{tabular}

\section{The Implementation of An-Nafs Learning Theories and Models}

The role of the teacher in this theory of learning is to collect verses of al-Qur'àn relating to each learning material. A teacher is required to have a treasury and understanding of the Qur'ān. Basically all fields of science are related to values, and the cues al-Quran, although not specifically mentioned in alQuran.

Students can be given learning tasks by the teacher, to search for verses of alQuran that relate to the problems and learning materials he studied. Teachers and students must have the understanding of the importance to develop the knowledge based on the Qur'an and Sunnah.

The components or principles of $A n$ Nafs Theory and Model learning are:

a. The principle of Ta'abbudiyah and the Embodiment of Amanah as the Khalifah of Allah. Educate, and learn should be understood as a form of servitude that is interpreted as worship to God and as a form of performing trust that mandated by God to man.

b. The principle of reading (iqra 'and recitations). Iqra 'or reading command, is the first word of the first down revelation received by Prophet Muhammad. The word iqra'is taken from the word قر which at first means "gathering". Another meaning of this word is, convey, study, read, explore, research, know the characteristics, and so forth (Shihab, 2006). The word قرأ repeats three times in
al-Quran on QS. Al-Isra ', 17: 14 and QS. Al-'Alaq, 19: 1 and 3. While the word invented from the root of the word in various forms, repeated as much as 17 times apart from the word al-Quran repeated 70 times. According to Shihab (2006), the reading object of qara'a's words concerns the reading that comes from god, and other objects. Thus the object of the read command is very broad.

c. The principles questioning and seeking answers. As explained by Sanjaya (2006), asking is a form of thinking process. Asking can be aimed at attracting students' attention, or tracing knowledge information, developing skills or testing. Practicing the skill of raising questions will raise the need for answers. That answers is the science. God illustrates the importance of asking questions in learning. "And $\mathrm{We}$ have not sent before you, save the men whom We have revelated unto them; then ask those who have knowledge if you do not know, (QS an-Nahl, 16:43)

d. Principle maximizes the potential of thought and zikr. Thinking and remembering is the essence of the learning process itself. Learning is maximizing the potential of the brain and the potential of Qalbu to form a personal uli al-bab. Allah says, "Verily in the creation of the heavens and the earth, and the alternation of night and day there are signs for those who are understanding, those who remember Allah while standing or sitting or in a lying-down order and they think about the creation of heaven and earth (saying): "Our Lord, You have not created this in vain, Glory to You, 
so save us from the torment of hell." ( $Q S$. Ali Imran, 190-191) The stages of $\mathrm{An}-\mathrm{Na}$ $f s$ learning begin with the setting of out put standards in general or learning objectives. The out put is the acknowledgment of the Godhead (QS. Ali Imran, 3: 190-191), the ability to serve God (QS. Al-An'am, 6: 161-162), and has a assertivenes, ruhama, ' redha Allah (QS. Al-Fath, 48: 29), and the realization of the well-being of the inner and outer lives (QS. Saba ', 34: 15).

Table 2. Learning Stages of An-Nafs

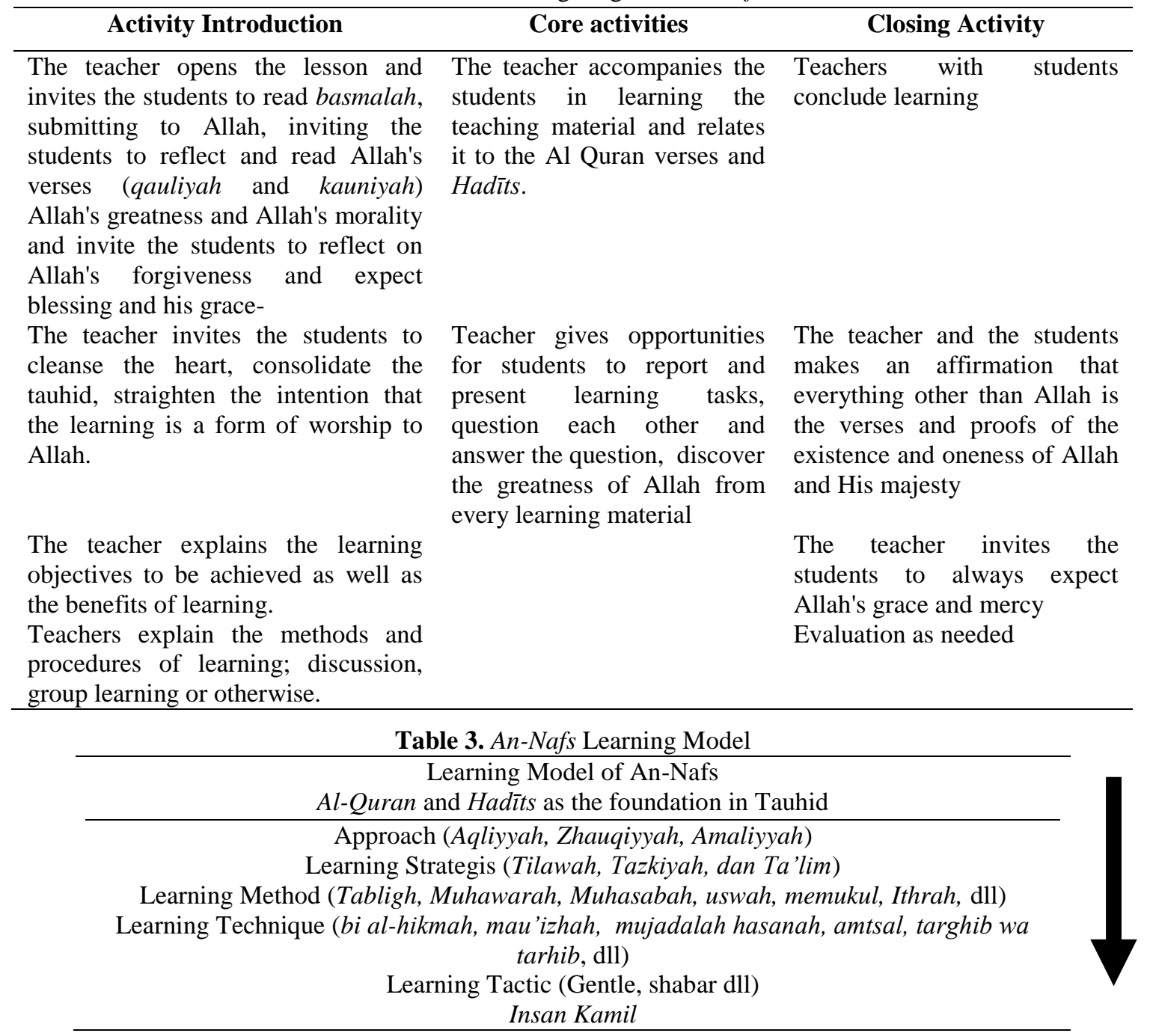

\section{The Response Of Religious Teachers At Elementary School In Palupuh Throught Theory And An-Nafs Learning Model}

The religious Teachers' Response was obtained from a questionnaire that consists of 16 questions and given to Islamic Religious teachers in Palupuh, Agam. It is given after an introduction to the theory and model of $A n$ Nafs learning. Questions in the questionnaire are divided into four sections: the response to the nature of learning and the philosophical basis of An-Nafs theory and model of learning, response to the approaches, strategies, methods, techniques and learning tactics used in the theory and model of annafs learning, response to the urgency and benefit of the application of An-Nafs learning theory and model in Islamic religious learning, and response to the implementation of steps of An-Nafs learning on Islamic relgious subjects. 


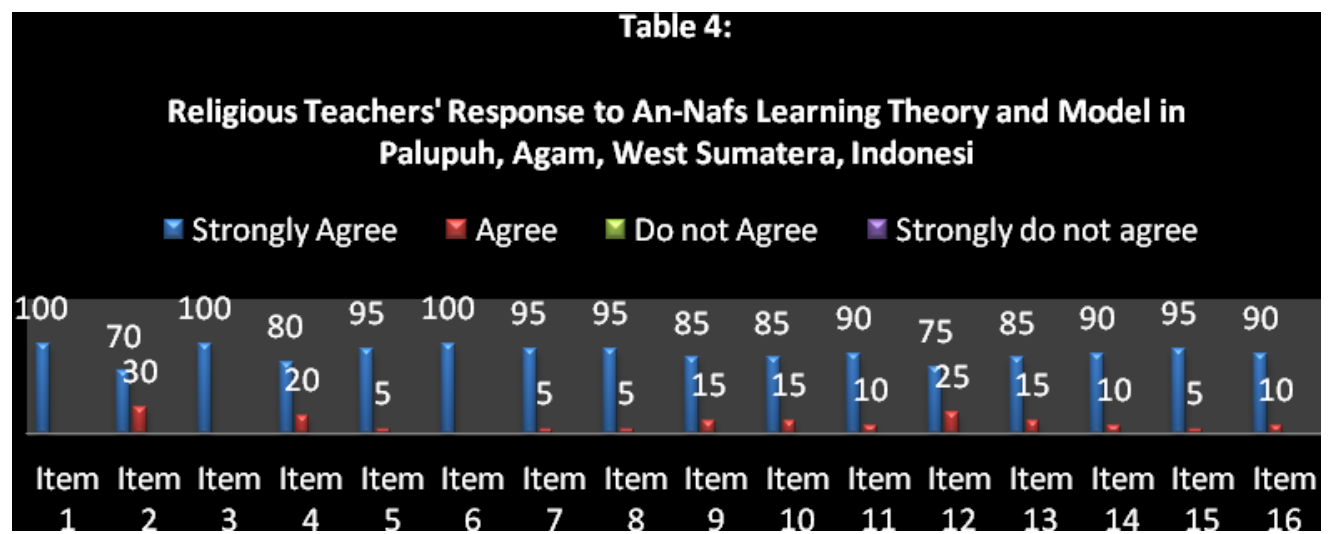

Description of teacher response :

1. Learning is essentially a process for the occurrence of changes in self (Nafs) as the potential human-psychological as the subject and object of education and learning.

2. An-Nafs Learning Theory and Model can help the real learning.

3. Educate, learn must be understood as a form of servitude to Allah, and as a form of doing mission that Allah given to the human.

4. Reading (iqra' and tilawah) is an important principle in learning.

5. Asking and searching for answers is an important principle in learning.

6. Thinking and zikirullah the essence of the learning process itself because learning is to maximize the potential of the brain and the potential of Qalbu to form uli al-bab personal.

7. Out put of the learning process is basically are there is awareness of the greatness of Allah, there is the ability to serve Allah, there is a firm attitude, ruhama '(love), there is a person who seek Allah redha, and there is the realization of the welfare of life and inner life.

8. 'Aqliyah Learning Approach (mind / logic), dezauqiyah, and 'amaliyah (doing to experience), is very important to do in learning Islamic religious integrated.

9. Tilawah Learning strategy (exploration of Allah's messages and signs of greatness of Allah) are helpful to achieve the goal of learning Islamic religious.

10. Tazkiyah learning strategy (cleansing the heart) is very helpful to achieve the goal of Islamic learning.

11. Ta'lim Learning strategy (knowledge transfer) is very helpful to achieve the goal of Islamic learning.

12. Combination of Tabligh learning method (lectures), Muhawarah (discussion and question and answer), Muhasabah, uswah, educational punishment, exclusion, etc., need to be applied in Islamic learning and effective to achieve the goal of Islamic learning.

13. The combination of Bi al-hikmah Learning Technique, mau'izhah hasanah, mujadalah hasanah, amtsal, targhib wa tarhib, etc., need to be applied in the learning of Islam and effective to achieve the goal of learning Islam.

14. Learning should be done gently and patiently.

15. I am interested in applying the theories and models of learning an-nafs in Islamic learning because these theories and models are urgent and very useful in achieving the goals of Islamic learning.

16. I am convinced that the implementation of the An Nafs Learning Model will help to realize the effective and efficient learning.

Based on Figure 1, all religious teachers respond are very well to the nature of 
learning and the philosophical basis of $A n$ Nafs theory and model of learning. Ruh is the most noble and most essential part of man because he is the puff of Allah SWT, he must be educated with the aim to facilitate the way to ma'rifat to Allah SWT and familiarize him and train him to really worship to Allah SWT. In this context, education and learning are very important role. With education and learning, the spirit (nafs) can be maintained its sanetity from the influence of material properties such as animals, evolving its potential, changing its behavior from ammarah, lawwamah into muthmainnah. This is what is meant by An-Nafs learning.

On average, all religious teachers in Palupuh responded very well to the approaches, strategies, methods, techniques and learning tactics used in the theory and model of an-nafs learning. The approaches, strategies, methods, techniques and learning tactics in the perspective of the theory and model of An-Nafs learning developed from the normative principles of Islam and the hadits of the Prophet Muhammad are believed to be more relevant to the needs of education itself. Respondents also responded very well to the urgency and benefits of applying the theory and model of An-Nafs learning in Islamic learning as well as excellent response also to the implementation of An-Nafs learning steps on Islamic religious subjects. The real educator is essentially Allah; the creator of man himself. On the other hand, man is a man entrusted by Allah to be His representative (khalifah) who among his duties is in the maintenance of this earth and education as the Word of Allah in Surat al'alaq ayat 1-5.

\section{CONCLUSION RECOMMENDATION}

AND

Based on the results of research and analysis of research data, it can be concluded that the response of religious teachers are very good on the application of the theory and model of learning An-Nafs, both on theoretical aspects, urgency, and the benefits of its application to the learning of Islam. Theory and model of learning An-Nafs as a model of theoretical and practical learning produces an out put that has awareness of Godhead, able to serve Allah and has the character and stance, ruhama ', Allah redha seeker as the capital of the realization of the prosperity of life and inwardness.

\section{REFERENCES}

Abuddin, N. (2011). Sejarah Pendidikan
Islam. Jakarta: Kencana.

Ægisdóttir, H. H., \& Pórhallsdóttir, P. E. (2004). Theories on migration and history of the North-Atlantic flora: a review. Jökull, 54, 1-16.

al-Muhasibi, al-H. (2010). Risalah alMustarsyidin. Tuntunan Bagi Para Para Pencari Penyejuk, Penj: Abdul Aziz, Jakarta: Qisthi ....

Baharuddin, E. B., \& Ismail, Z. B. (2015). 7 Domains of Spiritual Intelligence From Islamic Perspective. ProcediaSocial and Behavioral Sciences, 211, 568-577.

Bandura, A. (2005). The evolution of social cognitive theory. Great Minds in Management, 9-35.

Brown, K. L. (2003). From teacher-centered to learner-centered curriculum: Improving learning in diverse classrooms. Education, 124(1), 49-55.

Chalil, A. (2009). Pembelajaran Berbasis Fitrah. PT Balai Pustaka (Persero).

Darby, M. (2007). Debate: A teachinglearning strategy for developing competence in communication and critical thinking. American Dental Hygienists' Association, 81(4), 78-78.

de Corte, E. E., Verschaffel, L. E., Entwistle, N. E., \& Van Merriënboer, J. E. (2003). Powerful learning environments: Unravelling basic components and dimensions. Pergamon/Elsevier Science Ltd. 
Faruq, U. (2007). Risalah Qusyairiyah, Sumber Kajian Ilmu Tasawuf. Pustaka Amani, Jakarta.

Gustafson, K. L., \& Branch, R. M. (2002). What is instructional design. Trends and Issues in Instructional Design and Technology, 16-25.

Hale, M., \& Reiss, C. (2003). The Subset Principle in phonology: why the tabula can't be rasa. Journal of Linguistics, 39(2), 219-244.

Hamzah, R., Isa, K. M., \& Janor, R. M. (2010). Spiritual education development model. Journal of Islamic and Arabic Education, 2(2), $1-12$.

Illeris, K. (2004a). Adult education and adult learning.

Illeris, K. (2004b). Transformative learning in the perspective of a comprehensive learning theory. Journal of Transformative Education, 2(2), 7989.

Karabenick, S. A. (2003). Seeking help in large college classes: A personcentered approach. Contemporary Educational Psychology, 28(1), 3758.

Kobeisy, A. N. (2006). Faith-based practice: An introduction. Journal of Muslim Mental Health, 1(1), 57-63.

Kolb, D. A., Boyatzis, R. E., \& Mainemelis, C. (2001). Experiential learning theory: Previous research and new directions. Perspectives on Thinking, Learning, and Cognitive Styles, 1(8), 227-247.

Majid, A. (2011). Pendidikan Berbasis Ketuhanan. Bandung: CV Maulana Media Grafika.

Margono, S. (2005). Metodologi penelitian pendidikan. Jakarta: Rineka Cipta.
Merriam, S. B. (2001). Andragogy and selfdirected learning: Pillars of adult learning theory. New Directions for Adult and Continuing Education, 2001(89), 3-14.

Miller, G. A. (2003). The cognitive revolution: a historical perspective. Trends in Cognitive Sciences, 7(3), 141-144.

Mujib, A. (2012). Konsep pendidikan karakter berbasis psikologi Islam.

Mujib, A. (2017). Pengembangan Psikologi Islam Melalui Pendekatan Studi Islam. Jurnal Psikologi Islam, 1(1), 17-32.

Mujib, H. A. (2006). Kepribadian dalam psikologi Islam. PT Rajagrafindo Persada.

Munsoor, M. S. (2015). The soul (heart) and its attributes: an Islamic perspective with reference to self in Western psychology. Jurnal Akidah \& Pemikiran Islam, 16(1), 93-134.

Nashih'Ulwan, A. (2012). Pendidikan anak dalam Islam. Penerbit Insan Kamil Solo.

Nasrudin, N., \& Herdiana, I. (2015). Pengembangan Model Pendidikan Karakter Berdasarkan Sifat Fitrah Manusia. Jurnal Pendidikan Karakter, (3).

Nurdyansyah, N., \& Fahyuni, E. F. (2016). Inovasi Model Pembelajaran Sesuai Kurikulum 2013. Nizamia Learning Center.

O’Neil, H. F. (2014). Learning strategies. Academic Press.

Pang, V. O. (2001). Multicultural education: A caring-centered, reflective approach. ERIC.

Pathan, S. (2016). Islamic spirituality and social work interventions: The personin-relation approach. International Social Work, 59(3), 406-418. 
Pransiska, T. (2016). Konsepsi Fitrah Manusia Dalam Perspektif Islam Dan Implikasinya Dalam Pendidikan Islam Kontemporer. Jurnal Ilmiah Didaktika: Media Ilmiah Pendidikan Dan Pengajaran, 17(1), 1-17.

Razak, M. A. A. (2011). Human Nature: An Islamic Perspective. Journal of Islam in Asia (E-ISSN: 2289-8077), 8, 251274.

Rivauzi, A. (2014). Pemikiran Abdurrauf Singkel tentang Pendidikan dan Implikasinya pada Pondok Pesantren Nurul Yaqin Ringan-Ringan Pakandangan Padang Pariaman. Disertasi, PPs IAIN Imam Bonjol, Padang.

Rosidin, D. (2011). Al-Tarbiyah Meaning in Al-Qur'an and its Implication in Learning and Commentary Education Major in Arabic FPBS UPI. EDUCARE, 4(1).

Rothman, A., \& Coyle, A. (2018). Toward a framework for Islamic psychology and psychotherapy: an Islamic model of the soul. Journal of Religion and Health, 57(5), 1731-1744.

Sa'ari, C. Z. (2002). A Purification of Soul According to Sufis: A Study of alGhazali's Theory. Jurnal Akidah \& Pemikiran Islam, 3(1), 95-112.

Sad, M. I. (2004). Pendidikan Partisipatif Menimbang Konsep Fitrah dan Progresivisme John Dewey. Yogyakarta: Safira Lusania Press.

Sanaky, H. A. (2003). Paradigma Pendidikan Islam: Membangun Masyarakat Madani Indonesia. MSI, Universitas Islam Indonesia.

Sanaky, H. A. (2008). Metode Tafsir [Perkembangan Metode Tafsir Mengikuti Warna atau Corak Mufassirin]. Al-Mawarid Journal of Islamic Law, 18.
Sanjaya, W. (2006). Strategi pembelajaran berorientasi standar proses pendidikan. Jakarta: kencana.

Schaefer, K. M., \& Zygmont, D. (2003). Analyzing the teaching style of nursing faculty: Does it promote a student-centered or teacher-centered learning environment? Nursing Education Perspectives, 24(5), 238245.

Schmeck, R. R. (2013). Learning strategies and learning styles. Springer Science $\&$ Business Media.

Shihab, M. Q. (2006). Wawasan al-Qur'an tentang Zikir dan Doa. Lentera Hati Group.

Shihab, M. Q. (2007). “ Membumikan” AlQuran: fungsi dan peran wahyu dalam kehidupan masyarakat. Mizan Pustaka.

Simandan, D. (2013). Learning wisdom through geographical dislocations. The Professional Geographer, 65(3), 390395.

Solichin, M. M. (2007). Fitrah; Konsep dan Pengembangannya dalam Pendidikan Islam. TADRIS: Jurnal Pendidikan Islam, 2(2).

Sugiyono. (2008). Metode penelitian pendidikan:(pendekatan kuantitatif, kualitatif dan $R \& D$ ). Alfabeta.

Sutrisno, H. (2000). Metodologi research. Yogyakarta, Penerbit Psikologi Universitas.

Suyanto, B. (2005). Metode Penelitian Sosial: Berbagai Alternatif Pendekatan. Jakarta: Prenada Media.

Ubale, A. Z., \& Abdullah, A. H. (2015). The Effects Of Spirituality in Shaping The Human Behaviour:(An Islamic Perspective). International Journal of Academic Research in Business and Social Sciences, 5(9), 1-13. 
Ullrich, C. (2008). Descriptive and prescriptive learning theories. In Pedagogically Founded Courseware Generation for Web-Based Learning (pp. 37-42). Springer.

Vidyasagar, M. (2002). A theory of learning and generalization. Springer-Verlag.

Weinstein, C. E., Husman, J., \& Dierking, D. R. (2000). Self-regulation interventions with a focus on learning strategies. In Handbook of selfregulation (pp. 727-747). Elsevier.
Yahya, M. S. (2006). Strategi Pendidikan Islam Menghadapi Kemajuan Iptek. Insania, 11(1), 63-75.

Yang, B., Watkins, K. E., \& Marsick, V. J. (2004). The construct of the learning organization: Dimensions, measurement, and validation. Human Resource Development Quarterly, 15(1), 31-55. 